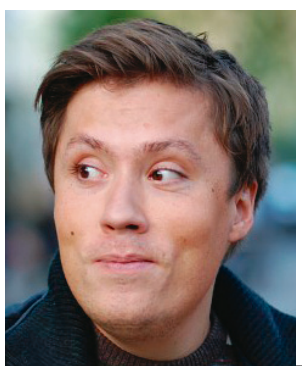

Jan Grue

Postdoktor ved Institutt for sosiologi og samfunnsgeografi

Universitetet i Oslo

Foto Ane Sangnes

\title{
Diagnose - svar eller spørsmål?
}

\section{Finmaskede diagnosekoder \\ garanterer ikke en riktig og \\ hensiktsmessig diagnose.}

For mange pasienter er det å få en diagnose en lettelse. Diagnosen kan virke både oppklarende og avklarende. Symptomene kan settes inn i en helhetlig ramme, og om man ikke kan håpe på å bli bedre, så har man i hvert fall noe å orientere forventningene sine mot.

I prinsippet burde de positive effektene vært særlig merkbare hos pasienter som har gått med plager i mange år. Men i denne gruppen kan diagnose også være en kilde til usikkerhet og konflikter. Det siste året har jeg arbeidet med et forskningsprosjekt som blant annet berører en av de mest komplekse diagnoseflokene i dagens Norge: kronisk utmattelsessyndrom (CFS) og myalgisk encefalopati (ME).

De to blir ofte slått sammen, og det er ikke så rart. Internasjonalt finnes det minst 12 kjente kriteriesett som nevner én eller begge diagnosene, og flere av disse beskriver dem som to sider av samme sak. Andre skiller. Noen kriterier er smale, andre er brede. Noen er eksklusjonsdiagnoser, i andre har man forsøkt å holde seg til klare kliniske markører. Noen peker i retning av psykososiale forklaringsmekanismer, andre ikke. Pasienter med ME, CFS eller ME/CFS-diagnose omtales ofte som én gruppe, men det kan være store forskjeller i diagnostiseringsprosessene de har vært igjennom.

Denne forskjellen er viktig, fordi diagnosene bærer historien med seg. Diagnosenes sosiologi er et nokså nytt forskningsfelt, men det er desto mer interessant og viktig. $\AA$ følge for eksempel den amerikanske psykiatrimanualen DSM fra den første utgivelsen i 1950-årene frem til forarbeidene for neste års femteutgave, er å se hvordan psykoanalysen forsvinner, mens farmakologien og statistikken kommer, ser og vinner. Sporene finnes imidlertid fortsatt. I tilfellet kronisk utmattelsessyndrom og myalgisk encefalopatifinnes fortiden blant annet gjennom koblingen til nevrasteni - en diagnose som klinger av det psykosomatiske, og som mange pasienter derfor aktivt vil unngå.

Pasienter som vil ha en somatisk diagnose, men som blir henvist til psykiatrien, er én kilde til konflikt. Men diagnoseeksplosjonen på det somatiske feltet er også problematisk. Fra ICD-9 til ICD-10 har antall koder $\varnothing$ kt fra rundt 13000 til rundt 68 000. Men mange diagnoser garanterer ikke mer presisjon. I en ny studie publisert i ISNR Public Health i 2012 ba Silje

Mæland og medarbeidere et utvalg på 56 norske allmennleger om å diagnostisere ni pasienter med sterke subjektive helseplager. De baserte seg på sykehistorier samt videoopptak der pasientene, spilt av skuespillere, var i konsultasjon med en lege. De ni pasientene fikk hver 13-31 ulike diagnoser over hele spekteret, inkludert psykologiske, nevrologiske, stoffskifterelaterte og uspesifiserte diagnoser.

Hvorfor er diagnose så viktig? Det er ikke bare et spørsmål om grensene mellom psyke og soma, heller ikke bare om adgang til trygderettigheter, men også om identitet. Her kan jeg bruke meg selv som eksempel. Jeg har en medfødt muskelsykdom som først, under en viss tvil, ble klassifisert som spinal muskelatrofi. Med den merkelappen fulgte blant annet en antakelse om ganske rask progrediering. Så, for noen år siden, havnet jeg i diagnos- tisk limbo - det var ikke spinal muskelatrofi likevel. Sykdommen hadde lenge oppført seg bedre enn prognosen tilsa, så overraskelsen var ikke så stor. Likevel var det som om en bærevegg i selvforståelsen min måtte nyoppføres. Usikkerheten medfører et helt annet krav til overvåking og fortolking - av symptomer, og hva de betyr.

Mange pasienter med kroniske plager er i liknende limbo. Mæland og medarbeidere indikerer at det ofte ikke finnes noen sikker vei ut. Diagnosen er gjerne ikke så definitiv og klargjørende som mange ønsker at den skal være. Da blir åpen kommunikasjon mellom lege og pasient, om usikkerheten og forbeholdene, svært viktig. Hvis man søker rundt på nettet, både som relativt fersk pasient og som erfaren lege, finner man raskt en lang rekke symptomer, behandlingstilbud og årsaksforklaringer på kronisk utmattelsessyndrom og myalgisk encefalopati og beslektede tilstander. Da er det fort gjort at man møtes med svært ulike forestillinger om hva som er galt og hva som kan gjøres.

På e-postlisten Eyr diskuterer mange fastleger sine frustrasjoner over ikke å få stilt diagnoser som er dekkende, hensiktsmessige, og som pasientene kan forholde seg til. I andre diskusjonsfora på nett forteller pasienter om hvordan diagnoser, særlig når de presenteres uten videre begrunnelser, kan fremstå som feilvurderinger, eller enda verre, som anklager. Disse bekymringene fordrer at diagnoser ikke bare blir anvendt, men diskutert - i all sin feilbarlighet.

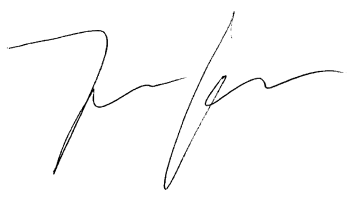

